\title{
Konsumsi dalam Perspektif Ekonomi Islam (Regresi Religiusitas terhadap Konsumerisme pada Mahasiswa UIN Syarif Hidayatullah Jakarta)
}

\author{
Herlina Yustati \\ Dosen Pengajar di IAIN Bengkulu
}

\begin{abstract}
Abstrak
Artikel ini mendiskusikan tentang bagaimana pemahaman dan penerapan keagamaan mempunyai pengaruh terhadap perilaku individu dalam hal ini perilaku konsumsi. Artikel ini membuktikan bahwa pemahaman keagamaan yang baik dan penerapannya akan memunculkan perilaku konsumsi yang baik pula. Perilaku konsumsi yang baik adalah perilaku konsumsi yang jauh dari gaya hidup hedonis dan berlebih-lebihan serta perilaku konsumsi yang hanya membeli apa yang dibutuhkan bukan apa yang diinginkan. Artikel ini juga membuktikan bahwa semakin tinggi tingkat religiusitas (pemahaman keagamaan dan penerapannya) maka akan semakin rendah tingkat konsumerisme (perilaku membeli yang menganggap barang mewah adalah ukuran kebahagiaan), hal ini dibuktikan dengan nilai t hitung yang bernilai negatif.
\end{abstract}

\begin{abstract}
This article discusses how the understanding and application of the religion have an influence on individual behavior in terms of consumption behavior. This article proves that a good understanding of religion and it application will bring a good consumption behavior. Good consumption behavior is the behavior of consumption away from the hedonistic lifestyle and extravagant and consumption behavior which only buy what is needed and not buy what is desired. This article also shows that who has a higher the level of religiosity (religious understanding and it application) will have the lower level of consumerism (buying behavior are considered luxury items is a measure of happiness), this is evidenced by the $t$ value is negative.
\end{abstract}

Kata kunci: konsumsi, konsumerisme, religiusitas, ekonomi Islam, mahasiswa

\section{A. Pendahuluan}

Ketika masyarakat mulai memasuki era postmodernisme ${ }^{1}$ keinginan dan kebutuhan telah menjadi sesuatu yang membaur, cair, tidak jelas, dan makin

\footnotetext{
${ }^{1}$ Postmodernisme adalah terminologi yang diaplikasikan secara luas dalam pembangunan teori kritis, filsafat, arsitektur, seni, kesusastraan, dan kebudayaan yang secara umum merupakan reaksi terhadap modernisme. (Nugroho, "Modernisme, Pos Modernisme serta kritik terhadap
} 
sulit dibedakan antara yang satu dengan yang lain. ${ }^{2}$ Ketika kebiasaan masyarakat lebih mengedepankan gengsi, berbelanja menjadi sebuah gaya hidup, berbagai fasilitas perbelanjaan tumbuh pesat di berbagai sudut kota, penggunaan kartu kredit makin masif, memudahkan serta menggoda masyarakat untuk membeli apapun seketika tanpa khawatir tabungannya cukup atau tidak, maka yang terjadi kemudian adalah lahirnya masyarakat konsumsi. ${ }^{3}$

Konsumsi menjadi isu penting selama dasawarsa 1980-an di Amerika ${ }^{4}$. Dalam beberapa tahun terakhir ini nampaknya hal yang sama juga terjadi pada masyarakat Indonesia ${ }^{5}$. Lahirnya masyarakat konsumen Indonesia ditandai dengan menjamurnya pusat perbelanjaan semacam shopping mall, industri waktu luang, industri mode atau fashion, industri kecantikan, industri kuliner, industri nasihat, industri gosip, real estate, apartemen, kawasan wisata, berdirinya sekolah-sekolah mahal (dengan label 'plus'), telepon seluler dan serbuan gaya hidup melalui industri iklan dan media. ${ }^{6}$

Berdasar data Survei Sosial Ekonomi Nasional (Susenas), biaya yang dikeluarkan rumah tangga miskin untuk pulsa lebih besar dibanding biaya listrik, padahal listrik merupakan kebutuhan mendasar. ${ }^{7}$ Data dari Gabungan Industri Kendaraan Bermotor Indonesia (Gaikindo) menyebutkan, terjadi peningkatan populasi mobil di Indonesia dalam kurun waktu 11 tahun terakhir. Kenaikannya mencapai dua kali lipat. Jumlah mobil pada tahun 2000 mencapai

Posmodenisme dalam Ilmu Ekonomi” Dinamika Pembangunan, vol 3, No 2, Desember 2006: 174183.

${ }^{2}$ Mashitoh Yaacob, "Ethics of Consumption: Individual Responsibility,” Jurnal Pengajian Umum Bil.5 (t.t): 42, lihat juga Bagong Suyanto, Sosiologi Ekonomi Kapitalisme dan Konsumsi di Era Masyarkat Postmodernisme (Jakarta: Kencana Prenada media Group, 2013), 106.

${ }^{3}$ Bagong Suyanto, Sosiologi Ekonomi Kapitalisme dan Konsumsi di Era Masyarakat Postmodernisme, 106. Ciri dari masyarakat konsumsi yang paling menonjol, yaitu bahwa arena konsumsi adalah kehidupan sehari-hari, dalam hal ini mal, hypermarket, dan supermarket sebagai sarana konsumsi memfasilitasi berbagai aktivitas masyarakat ikut andil dalam membentuk sikap dan perilaku konsumen. Nuansa kemewahan dan situasi-kondisi nyaman dalam perpaduan seni (musik) dan budaya menyebabkan konsumen merasa hanyut dalam suasana bahagia, namun sering kali dibuat setengah tidak sadar dalam mengambil keputusan berbelanja berbagai barang produksi yang beraneka ragam yang sebenarnya tidak mereka butuhkan. (Fadhilah, "Relevansi logika sosial Konsumsi dengan Budaya Konsumerisme Dalam Perspektif Epistemologi Jean Baudrillard", Jurnal Kybernan, Vol. 2, No. 1 (Maret 2011), 43).

${ }^{4}$ Martin J. Lee, Consumer Culture Reborn, The Cultural Politics of Consumption (LondonNew York: Routledge , 1993), iv.

${ }^{5}$ Jumlah penduduk indonesia sampai tahun 2010 adalah 237.641.326, data diperoleh dari website Badan Pusat Statistik http://www.bps.go.id/

${ }^{6}$ Idi Subandy Ibrahim, Budaya Populer Sebagai Komunikasi (Yogyakarta Jalasutra, 2007), 133.

${ }^{7}$ Bambang, HP kena pajak barang mewah orang miskin lebih banyak pulsa daripada bayar listrik (Minggu, 1 September 2013), http://www.poskotanews.com/2013/09/01/hp-kena-pajakbarang-mewah orang-miskin-lebih-banyak-beli-pulsa-darpada-bayar-listrik/ (diakses 16 September 2013). 
5,04juta unit. Jumlah tersebut meroket 117,7 persen menjadi 10,97 juta unit pada Mei 2012. ${ }^{8}$

Saat ini banyak keluarga muda yang memilih mengontrak rumah tapi punya mobil mewah dibandingkan membeli rumah tapi hanya punya motor atau memilih naik angkutan umum. Padahal, rumah adalah investasi masa depan yang seharusnya diutamakan. ${ }^{9}$ Bank Dunia mencatat sekitar 134 juta jiwa (56\%) rakyat Indonesia membelanjakan uangnya antara 2-20 USD setiap hari. Kenyataan lainnya, saat ini Indonesia berada di peringkat kedua negara paling konsumtif di dunia, dilihat dari transaksi kartu kredit yang mencapai 250 triliun/tahun, melonjak berkali lipat dari anggaran negara yang hanya 1.200 triliun/tahun. ${ }^{10}$ Ribuan orang antri membeli gadget terbaru, tiket konser ludes terjual, restoran-restoran kewalahan menerima pelanggan, dan mall tak pernah sepi pengunjung.

Fenomena ini ternyata tidak hanya terjadi di level masyarakat umum, tetapi juga terjadi pada mahasiswa. ${ }^{11}$ Keberadaan mall atau pusat perbelanjaan menjadikan generasi muda sasaran empuk konsumen yang disasarnya. Konsumen mall sendiri sangat beragam, mulai dari anak-anak hingga orang tua. Mahasiswa masuk dalam kelompok sasaran konsumen mall, karena mereka merupakan kelompok keluarga produktif, karena kebutuhan belanja mahasiswa cukup banyak dan beragam. Mall merupakan indutsri komersialiasi dan komoditisasi dengan prinsip bagaimana menjual barang. Secara sosiologis, mall membentuk masyarakat menjadi over-consumption karena memberikan pelayanan yang terpadu. Sehingga tidak mengherankan jika konsumerisme

\footnotetext{
${ }^{8}$ Ardyan Mohamad, “Tradisi Pamer Mobil Incar Masyarakat Konsumtif,” (Minggu, 23 September 2012),

http://www.merdeka.com/uang/tradisi-pamer-mobil-incar-masyarakat konsumtif-iims2012-1.html (diakses 16 September 2013). 2012),

${ }^{9}$ Yemima Lintang Khastiti, “konsumtif yang nggak bikin miskin adakah” (14 Februari

http://www.fimela.com/read/2012/02/14/konsumtif-yang-nggak-bikin-miskin-adakah, (di akses 16 September 2013). 2012),

${ }^{10}$ Yemima Lintang Khastiti “konsumtif yang nggak bikin miskin adakah” (14 Februari

http://www.fimela.com/read/2012/02/14/konsumtif-yang-nggak-bikin-miskin-adakah, (di akses 16 September 2013).

${ }^{11}$ Mahasiswa merupakan pelajar yang menempuh pendidikan di perguruan tinggi, tujuan pendidikan di perguruan tinggi adalah menghasilkan warga negara menjadi sarjana yang bertakwa kepada Tuhan yang Maha Esa, bersikap dan bertindak sesuai dengan ajaran agama, dan memiliki tenggang rasa terhadap pemeluk agama lain. Simuh, dkk, Islam dan Hegemoni Sosial (Jakarta: Mediacita, 2002), 119.
} 
mempengaruhi mahasiswa sangat tinggi karena sering kali mahasiswa terjebak dengan penawaran-penawaran yang di luar rasio. ${ }^{12}$

Berbagai macam gaya hidup yang muncul dari kegiatan konsumsi diantaranya nge-mall, clubbing, fitnes, hangout di kafe dan lain-lain. Saat ini di sekeliling kebanyakan kampus di Indonesia telah bermunculan ruang-ruang konsumsi berbentuk rumah bernyanyi, kafe, mall serta berbagai macam fasilitas lainnya untuk menghabiskan waktu selain di himpunan atau sekretariat organisasi yang ada di kampus. Ruangan luas yang ber-AC dengan hidangan pencuci mata yang mengkilap terbukti mampu memuaskan keinginan mahasiswa untuk mengonsumsi. Mahasiswa lebih banyak menghabiskan waktu di ruang-ruang konsumsi tersebut sehingga ruang-ruang kecil sekretariat kemahasiswaan di kampus menjadi sepi dan kosong.

Hidup hedonis seperti ini melanda sebagian besar mahasiswa. Budaya konsumerisme menjadi trend mahasiswa. Mal-mal penuh dengan beragam mahasiswa, mahasiswa lebih memprioritaskan waktu luang dengan mondarmandir dibandingkan menghabiskan waktu untuk kepentingan orang banyak. ${ }^{13}$ Hal-hal tersebut di atas merupakan beberapa indikasi bahwa konsumerisme telah mewarnai kehidupan mahasiswa, begitupun secara umum terlihat melanda mahasiswa UIN Syarif Hidayatullah.

Budaya konsumerisme merupakan budaya pemborosan dan berfoya-foya karena melakukan konsumsi berlebihan. Dalam Al-quran surat al-Isra>ayat 26$27^{14}$, al-A'rał ayat $31^{15}$, dan al-Nisa>ayat $5^{16}$, Allah melarang seorang muslim untuk melakukan israß (melampaui batas hemat dan keseimbangan dalam berkonsumsi), dan tabdhik (melakukan konsumsi secara berlebihan dan tidak proporsional).

\footnotetext{
${ }^{12}$ Margaret Puspitarini, “ Mall Tingkatkan Konsumerisme Mahaasiswa”, (Jumat, 3 Agusutus 2012), http://kampus.okezone.com/read/2012/08/03/373/672745, (diakses, 18 Oktober 2013).

${ }^{13}$ Adnan, “Tiga Tipe Mahasiswa di Kampus,” (Kamis,31 Januari 2013)

http://www.republika.co.id/berita/jurnalismewarga/wacana/13/01/31/mhhaiq-tiga-tipemahasiswa-di-kampus (diakses, 16 Agustus 2014)

${ }^{14}$ Dan berikanlah haknya kepada kerabat dekat, juga kepada orang miskin dan orang yang dalam perjalanan; dan janganlah kamu menghambur-hamburkan (hartamu) secara boros. Sesungguhnya orang-orang yang pemboros itu adalah saudara setan itu sangat ingkar kepada Tuhan-Nya.

${ }^{15}$ Wahai anak cucu Adam! Pakailah pakaianmu yang bagus pada setiap (memasuki) masjid, makan dan minumlah, tetapi jangan berlebihan. Sungguh, Allah tidak menyukai orang yang berlebih-lebihan.

${ }^{16}$ Dan janganlah kamu serahkan kepada orang yang belum Sempurna akalnya, harta (mereka yang ada dalam kekuasaan) kamu yang dijadikan Allah sebagai pokok kehidupan. berilah mereka belanja dan Pakaian (dari hasil harta itu) dan ucapkanlah kepada mereka kata-kata yang baik.
}

28 I INDO-ISLAMIKA, Volume 2, Nomor 2, 2015/1437 
Faktor-faktor yang mempengaruhi keputusan untuk membeli suatu komoditas atau mengonsumsi suatu komoditas diantaranya adalah pendapatan, lingkungan, dan lain-lain. Adapun faktor internal yang dapat mengurangi konsumerisme diantaranya konsep diri, konformitas, dan lain-lain. Namun beberapa penelitian menunjukkan bahwa agama (baik dari afiliasi keagamaaan maupun religiusitas) mempengaruhi keputusan seseorang dalam mengonsumsi suatu komoditas. Agama yang didalamnya mencakup akhlaq merupakan nilainilai dasar yang ditanamkan terhadap mahasiswa UIN Syarif hidayatullah, hal tersebut dapat dilihat melalui mata kuliah dasar yang diajarkan pada setiap jurusan di semester awal perkuliahan. Sehingga menarik untuk diteliti apakah nilai-nilai agama yang akan berimplikasi pada tingkat religiusitas mahasiswa memiliki pengaruh terhadap perilaku konsumsi di kalangan mahasiswa.

Mahasiswa UIN sebagai mahasiswa muslim yang mempelajari Islam sehingga mengetahui bahwa pengetahuan menjadi bagian yang penting, begitu juga pengetahuan tentang konsumsi yang baik yang sesuai ajaran Islam. Sebagai mahasiswa yang ditanamkan ajaran agama diharapkan mampu membedakan mana kebutuhan dan mana keinginan, karena pada dasarnya kebutuhan dan keinginan adalah dua hal yang berbeda kebutuhan merupakan sesuatu yang harus dipenuhi untuk keberlangsungan hidup sedangkan keinginan tidak harus selalu dipenuhi karena tidak akan mengganggu keberlangsungan hidup. Keinginan biasanya identik dengan menyukai barang-barang mewah diluar kebutuhan. Kegemaran terhadap barang-barang mewah atau materealistis dikenal dengan konsumerisme.

Menurut Safiek Mokhlis religiusitas nampaknya memiliki peranan yang bisa menentukan perilaku konsumsi sehingga dapat dimasukkan sebagai penentu kemungkinan konsumsi atau orientasi belanja pada perilaku konsumen. ${ }^{17}$ Latar belakang pendidikan sebelum menjadi mahasiswa UIN dan latar belakang keluarga yang berbeda akan menunjukkan tingkat religiusitas yang berbeda dan tingkat konsumerisme yang beragam di kalangan mahasiswa, sehingga penulis tertarik untuk meneliti pengaruh religiusitas terhadap konsumerisme mahasiswa UIN Syarif Hidayatullah Jakarta.

Dalam penelitian ini metode yang digunakan oleh penulis adalah metode penelitian dengan menggunakan pendekatan kuantitif. Penelitian ini dirancang sebagai sebuah penelitian lapangan yang menggunakan kuesioner untuk pengumpulan datanya. Sehingga pemahaman terhadap hasil analisis tersebut diinterpretasikan kedalam bahasa kualitatif. Data primer diperoleh langsung dari mahasiswa UIN Syarif Hidayatullah Jakarta melalui kuesioner. Untuk

${ }^{17}$ Safiek Mokhlis, "Relevancy and Measurement of Religiosity in Consumer Behavior Research,” International Business Reasearch Vol. 2, No. 3. (2009): 75. 
melengkapi data penulis juga melakukan wawancara dan observasi. Data sekunder pada penelitian untuk membantu peneliti menganalisis secara kualitatif hasil penelitian. Data sekunder diperoleh dari sumber tertulis berupa sumber buku, jurnal, artikel, majalah dan sumber internet.

Adapun sampel pada penelitian ini sebanyak 100 Orang mahasiswa dari 11 fakultas di UIN Syarif Hidayatullah dengan jumlah mahasiswa pada masingmasing fakultas tidak sama. Teknik sampling pada penelitian ini adalah purposive sampling (pengambilan sampel berdasarkan tujuan) ${ }^{18}$, yang ditujukan pada mahasiswa yang memiliki uang saku minimal Rp.2.000.000. Alat ukur religiusitas yang digunakan dalam penelitian ini adalah alat ukur tingkat religiusitas CMIR (Comprehensive Measure of Islamic Religiosity) menurut Habib Tiliouine dan Abbes Belgoumidi. Untuk mengukur perilaku konsumsi terhadap gejala konsumerisme peneliti menggunakan alat ukur (CSI) Consumer Styles Inventory menurut George B. Sproles and Elizabeth L. Kendall.

Untuk mengetahui bagaimana tingkat konsumerisme mahasiswa, dan untuk mengetahui bahwasanya religiusitas memiliki pengaruh terhadap konsumerisme, dan besarnya kontribusi religiusitas terhadap konsumerisme pada mahasiswa UIN Syarif Hidayatullah penulis menggunakan analisis regresi linier sederhana. Hasil uji regresi tersebut selanjutnya di perkuat dengan data kualitatif melalui wawancara, observasi dan melalui referensi yang berkaitan dengan penelitian penulis. Untuk membantu analisis tersebut peneliti menggunakan alat bantu software SPSS, software ini membantu peneliti dalam melakukan distribusi data, uji validitas dan reliabilitas, uji asumsi klasik dan uji regresi linier sederhana.

\section{B. Religiusitas dan Konsumerisme}

Ideologi keagamaan banyak berpengaruh pada perilaku masyarakat tanpa kecuali baik itu dalam dunia bisnis, dunia kerja, dan lain sebagainya. ${ }^{19}$ Dari istilah agama kemudian muncul apa yang dinamakan religiusitas. Glock dan Stark sebagaimana dikutip oleh Fuad Nashori dan Rachmy Diana Mucharam merumuskan religiusitas sebagai komitmen religius (yang berhubungan dengan agama atau keyakinan iman), yang dapat dilihat melalui aktivitas atau perilaku individu yang bersangkutan dengan agama atau keyakinan iman yang dianut. Religiusitas diartikan sebagai seberapa jauh pengetahuan, seberapa kokoh

18 Dalam teknik ini yang akan diambil sebagai anggota sampel diserahkan pada pertimbangan peneliti yang sesuai dengan maksud dan tujuan penelitian. Irawan Suharto, Metode Penelitian Sosial Suatu Teknik Penelitian Bidang Kesejahteraan Sosial dan Ilmu Sosial Lainnya, (Bandung: PT Remaja Rosdakarya, 2008), 63.

${ }^{19}$ Muhammad Djakfar, Agama, Etika, dan Ekonomi wacana menuju pengembangan Ekonomi Rabbaniyah (Malang: UIN Malang Press , 2007), 237. 
keyakinan, seberapa banyak pelaksanaan ibadah dan kaidah dan seberapa dalam penghayatan atas agama yang dianutnya. Bagi seorang muslim, religiusitas dapat diketahui dari seberapa jauh pengetahuan, keyakinan, pelaksanaan, dan penghayatan atas agama Islam. ${ }^{20}$

Johnson, Jang, Larson dan Li yang dikutip oleh Mahesh Patel memaknai Religiusitas atau komitmen agama adalah sejauh mana individu berkomitmen untuk agama dan mengakui agamanya dan ajaran-ajarannya, sehingga sikap dan perilaku individu mencerminkan komitmen ini. ${ }^{21}$ Sejauh mana seseorang menganut nilai-nilai agamanya, keyakinan dan praktik serta menggunakan keyakinan dan mempraktekkannya dalam kehidupan sehari-hari. Dugaannya adalah bahwa orang yang sangat religius akan menjalani kehidupan dunia melalui pemahaman agamanya dan dengan demikian akan mengintegrasikan ajaran agamanya dalam hidupnya. ${ }^{22}$

Religiusitas muslim adalah keyakinan keagamaan seseorang berdasarkan tauhid dan bagaimana keyakinan tersebut berimplikasi dalam kehidupan seharihari. $^{23}$ Pada penelitian ini konsep religiusitas yang dimaksud adalah religiusitas merupakan serangkaian tindakan keagamaan yang dilakukan oleh seseorang sebagai bukti ketaatan dan kepatuhan terhadap agama yang dianutnya, dalam hal ini khususnya agama Islam.

Konsep religiusitas telah menjadi pemikiran banyak ilmuwan sosial yang mengamati mengapa sebagian orang lebih religius daripada sebagian yang lain, sehingga hal ini mendorong perkembangan pemikiran untuk mengukur religiusitas secara kuantitatif, dan secara potensial religiusitas dapat diukur dengan menggunakan pendekatan multi-dimensional. ${ }^{24}$ Meskipun tidak ada konsensus dalam literatur mengenai jumlah pasti dimensi religiusitas, sebagian besar peneliti setuju bahwa religiusitas adalah multidimensi yang mengharuskan

\footnotetext{
${ }^{20}$ Fuad Nashori dan Rachmy Diana Mucharam, Mengembangkan Kreativitas Dalam Perspektif Psikologi Islam (Yogyakarta: Menara Kudus 2002), 71.

${ }^{21}$ Mahesh Patel, "Influence of Religion on Shopping Behaviour of Consumers-An Exploratory Study”, 72.

${ }^{22}$ Everett L. Worthington, and others, "The religious commitment inventory-10: development, refinement and validation of a brief scale for research and counselling”, Journal of Counselling Psychology 50 (1): 85.

${ }^{23}$ Steven Eric Krauss, , “The Muslim Religiosity-Personality Measurment Inventory (MRPI)'s Religiosity Measurment Model: Toward Filling The Gaps in Religiosity Research on Muslim,” Pertanika Journal of Social Science and Humanity, 13(2) (Serdang: University Putra Malaysia Press, 2005), 174.

${ }^{24}$ Morton B. King and Richard A. Hunt, ”Measuring the Religious Variable: Replication,” Journal for the Scientific Study of Religion, Vol. 11, No. 3 (Sep., 1972): 240, lihat juga Morton King, "Measuring the Religious Variable: Nine Proposed Dimensions," Journal for the Scientific Study of Religion, Vol. 6, No. 2 (Autumn, 1967): 173, Susy Y.R. Samie-Herman, Teori Ekonomi Mikro Agama Pengaruh Religiusitas Terhadap Perilaku Ekonomi, 27.
} 
komponen untuk dipelajari secara individual. ${ }^{25}$ Isi dan jumlah dimensi religiusitas bervariasi dan tergantung pada sifat penelitian, tujuan dan konteksnya. ${ }^{26}$

Pada penelitian konsumen Allport dan Ross yang dikutip oleh Gregory M. Herek mengukur religiusitas dengan dua dimensi yaitu dimensi intrinsik yang merupakan penghayatan atau pemahaman beragama seseorang yang timbul dari dalam diri seseorang, yang kedua yaitu ekstrinsik yang merupakan penghayatan atau komitmen beragama seseorang yang muncul dari luar dirinya. ${ }^{27}$ Wilkes dalam Hamza Khraim menggunakan empat dimensi untuk mengukur tingkat religiusitas yaitu, kehadiran di gereja, pentingnya nilai-nilai agama, kepercayaan terhadap nilai-nilai agama dan keagamaan yang dirasakan sendiri. ${ }^{28}$

Dimensi-dimensi religiusitas di atas merupakan dimensi-dimensi religiusitas yang biasa digunakan di barat pada masyarakat yang beragama kristen dan yahudi dan beberapa masyarakat beragama hindu dan budha di negara lainnya. ${ }^{29}$ Beberapa peneliti muslim merasa perlu untuk membuat dimensi-dimensi yang sesuai dengan ajaran Islam, karena muslim membutuhkan

${ }^{25}$ Brian J. O'Connell, “Dimensions of Religiosity among Catholics” Review of Religious Research, Vol. 16, No. 3, (Spring,1975): 198. Lihat juga Safiek Mokhlis, "Relevancy and Measurement of Religiosity in Consumer Behavior Research,” International Business Research Vol. 2, No. 3 (2009): 81.

${ }^{26}$ Safiek Mokhlis, "Relevancy and Measurement of Religiosity in Consumer Behavior Research," 77.

${ }^{27}$ Gregory M. Herek, "Religious Orientation and Prejudice: A Comparison of Racial and Sexual Attitudes,” Personality and Social Psychology Bulletin 13(1) (1987): 34, lihat juga Muhammad Syukri Salleh, "Religiosity in Development: A Theoretical Construct of an IslamicBased Development,” International Journal of Humanities and Social Science Vol. 2 No. 14 (Special Issue-July 2012): 267, Ronald Rulindo and Amy Mardhatillah, "Spirituality, Religiousity And Economic Performances Of Muslim Micro Enterpreneurs," $8^{\text {th }}$ International Conference on Islamic Economics and Finance http://www.conference.qfis.edu.qa/app/media/311 (accessed November 21,2013): 3 dan Scott J. Vitell, “The Role of Religiosity in Business and Consumer Ethics: A Review of the Literature,” Journal of Business Ethics (2009): 157.

${ }^{28}$ Hamza Khraim, "Measuring Religiosity in Consumer Research from Islamic Perspective,” International Journal of Marketing Studies Vol. 2, No. 2; (November 2010): 168.

${ }^{29}$ Beberapa penelitian yang menggunakan dimensi religiusitas pada agama selain Islam, diantaranya adalah lima dimensi menurut Rodney Stark and Charles Y. Glock digunakan untuk mengukur tingkat religiusitas masyarakat amerika utara yang beragama kristen, Stefan Huber and Odilo W. Huber, “ The Centrality of Religiosity Scale (CRS)” Religions (2012): 712. Lihat juga Y. Fukuyama, “The Major Dimensions of Church Membership,” Review of Religious Research 2 (1960): 154-161. Brian J. O'Connell, “Dimensions of Religiosity among Catholics,” 198-207, Nedjet Delener, "Religious Contrasts in Consumer Decision Behaviour Patterns: Their Dimensions and Marketing Implications," 8-52, John M. Finney, “A Theory of Religious Commitment,” Sociological Analysis, Vol. 39, No. 1 (Spring, 1978), 19-35, Everett L. Worthington, Jr, dkk, "The Religious Commitment Inventory-10: Development, Refinement, and Validation of a Brief Scale for Research and Counseling,” 84-96.

32 I INDO-ISLAMIKA, Volume 2, Nomor 2, 2015/1437 
dimensi religiusitas yang relatif berbeda ${ }^{30}$ diantaranya adalah Taai(1985) yang dikutip oleh Hamza Khraim menggunakan dua dimensi yaitu kepercayaan dan praktek keagamaan, Albehairi and Demerdash (1988) menggunakan dua dimensi religiusitas yaitu intrinsik dan ekstrinsik, dan Albliakhi (1997) menggunakan tiga dimensi yaitu kepercayaan, sikap dan praktek keagamaan. ${ }^{31}$

Abdul Razak Kamaruddin dengan MRV (Muslim Religious Value) ${ }^{32}$, Wilde dan Joseph (1997) sebagaimana dikutip oleh Muhammad Syukri Salleh mengukur religiusitas muslim dengan sikap dan pengalaman, teori religiusitas ini dikenal dengan MARS (Muslim Attitude Religion Scale). ${ }^{33}$ Menurut Hamdani (2000) sebagaimana dikutip Steven E.Krauss mengukur religiusitas dengan RI (Religious Index). Steven. E’Krauss (2005) membuat MRPI (Moslim Religiousity Personality Inventory) ${ }^{34}$. Hamza Khraim menggunakan empat dimensi untuk mengukur tingkat religiusitas, yaitu jasa keuangan Islam, pendidikan agama, pengetahuan permasalahan Islam terbaru, dan penggunaan produk. $^{35}$

Sebuah usaha untuk membuat pengukuran religiuistas Islam yang lebih komprehensif dan lengkap diupayakan oleh Habib Tiliouine dan Abbes Belgoumidi (2009). Selain keyakinan agama dan perilaku keagamaan atau praktek seperti disebut oleh dimensi religiusitas sebelumnya, maka Tiliouine \& Belgoumidi mengusulkan altruism dan enrichment sehingga menjadi empat dimensi yang dinamakan CMIR (Comprehensive Measure of Islamic Religiosity). ${ }^{36}$

Pertama, Kepercayaan Agama yang berisi 17 item yang berhubungan dengan hal-hal iman, seperti percaya kepada Allah, hari pembalasan, neraka, surga, dan lain-lain. Kedua, Praktek Agama yang berisi 20 item yang

${ }^{30}$ Steven Eric Krauss, dkk, “The Muslim Religiosity-Personality Inventory (MRPI): Towards Understanding Differences in the Islamic Religiosity among the Malaysian Youth,” 176.

${ }^{31}$ Hamza Khraim, "Measuring Religiosity in Consumer Research from Islamic Perspective,” 175.

${ }^{32}$ Abdul Razak Kamaruddin, "Religiosity and Shopping Orientation: A Comparative Study of Malaysia and Thailand Consumers," 4.

${ }^{33}$ Muhammad Syukri Salleh, "Religiosity in Development: A Theoretical Construct of an Islamic-Based Development,” International Journal of Humanities and Social Science Vol. 2 No. 14 (Special Issue - July 2012): 269.

${ }^{34}$ Steven Eric Krauss, dkk, “The Muslim Religiosity-Personality Inventory (MRPI): Towards Understanding Differences in the Islamic Religiosity among the Malaysian Youth,” 173186, lihat juga Steven Eric Krauss,dkk, “Adaptation of a Muslim Religiosity Scale for Use with Four Different Faith Communities in Malaysia,” Review of Religious Research, Vol. 49, No. 2 (Dec., 2007): 47-164.

${ }^{35}$ Hamza Khraim, "Measuring Religiosity in Consumer Research from Islamic Perspective,” 171.

${ }^{36}$ Muhammad Syukri Salleh, "Religiosity in Development: A Theoretical Construct of an Islamic-Based Development,” 269. 
berhubungan dengan hal-hal praktis seperti shalat, puasa, menghindari minuman beralkohol, menutup aurat, dan lain-lain. Ketiga, Altruisme Agama yang berisi 12 item yng berhubungan dengan aspek relasional, seperti patuh kepada orang tua, kerabat, tetangga, dan menasihati orang lain. Dan keempat, yang memperkaya pemahaman agama yang berisi 11 item yang berhubungan dengan kegiatan yang memperluas pengetahuan agama dan pengalaman spiritual, seperti membaca buku-buku agama, menghadiri pertemuan keagamaan, menyaksikan acara keagamaan di televisi dan radio,dan lain-lain. ${ }^{37}$

Agama dan pemahaman keagamaan melalui indikator-indikatornya akan menunjukkan tingkat religiusitas. Melalui pemahaman keagamaan secara komprehensif maka akan diketahui bagaimana mengalokasikan pendapatan melalui konsumsi yang tidak berlebihan, walaupun banyak faktor yang menyebabkan terjadinya konsumsi yang tidak sesuai dengan ajaran Islam tersebut.

Di era postmodernisme konsumsi tidak lagi sekedar sebagai kegiatan pemenuhan kebutuhan-kebutuhan dasar dan fungsional manusia saja. Seseorang berkonsumsi bukan sebagai upaya untuk pemenuhan kebutuhan, namun lebih sebagai pemenuhan keinginan. Konsumsi telah menjadi budaya yaitu budaya konsumerisme $^{38}$. Masyarakat konsumsi diidentikkan dengan masyarakat pertumbuhan yang dalam prosesnya merupakan lingkaran setan pertumbuhan yang dihubungkan dengan pemborosan. ${ }^{39}$

Dua hal yang mempengaruhi konsumen dalam mengonsumsi suatu komoditas, yakni ia mempunyai pilihan (preference) dalam meminta komoditas dan mempunyai keterbatasan untuk memenuhi keinginannya. ${ }^{40}$ Konsumsi $^{2}$ berlebih-lebihan merupakan ciri khas masyarakat yang tidak mengenal tuhan, dikutuk dalam Islam dan disebut dengan istilah israæ (pemborosan) atau (menghambur-hamburkan harta tanpa guna) berarti menggunakan harta dengan cara yang salah, yakni, untuk menuju tujuan-tujuan yang terlarang seperti penyuapan, hal-hal yang melanggar hukum atau dengan cara yang tanpa

\footnotetext{
${ }^{37}$ Habib Tiliouine dan Abbes Belgoumidi, “An Exploratory Study of Religiosity, Meaning in Lifeand Subjective Wellbeing in Muslim Students from Algeria,” The International Society for Quality of Life Studies (ISQOLS) Springer (2009): 115.

${ }^{38}$ Konsumerisme adalah paham atau gaya hidup yang menganggap barang-barang (mewah) sebagai ukuran kebahagiaan, kesenangan, dan sebagainya; gaya hidup yang tidak hemat. Sedangkan konsumtif diartikan bersifat konsumsi (hanya memakai, tidak menghasilkan sendiri). http://bahasa.kemdiknas.go.id/kbbi/index.php (diakses 15 September 2013).

${ }^{39}$ Jean P. Baudrillard., Masyarakat Konsumsi, terj. Wahyunto, (Kreasi Wacana: Yogyakarta, 2011), 33.

${ }^{40}$ Masyhuri, Ekonomi Mikro (Malang: UIN Malang Press, 2007), 23.
} 
aturan. $^{41}$ Tabdhiæ juga berarti menghambur-hamburkan kekayaan yang telah dianugerahkan hanya untuk memuaskan kebutuhan yang tidak dihalalkan, keinginan yang haram yang tidak bermoral, seperti mabuk-mabukan, berjudi dan lain sebagainya. ${ }^{42}$

Adapun pada era saat ini berlebih-lebihan lebih dikenal dengan konsumerisme. Konsumerisme merupakan keinginan seseorang untuk mengonsumsi suatu komoditas secara berlebihan. Keinginan menurut ilmu ekonomi berhubungan dengan kebutuhan manusia ditambah dengan kemauan dan kemampuan untuk memenuhi kebutuhan-kebutuhan tersebut. Keinginan manusia itu tidak terbatas, karena manusia hampir tidak pernah berhenti berkeinginan. Jika satu keinginan terpenuhi akan muncul keinginan berikutnya sehingga manusia memperjuangkan keinginan tersebut tanpa berhenti, namun semuanya tidak memberi kepuasan kepadanya. ${ }^{43}$

Konsumerisme dipengaruhi oleh faktor intern dan ekstern diantaranya adalah tuntutan gaya hidup, media massa, sarana yang menunjang konsumerisme, dan lain sebagainya. Dari beberapa faktor tersebut beberapa peneliti membuat Indikator atau aspek-aspek yang mempengaruhi perilaku konsumen yang diukur, dipelajari, dan dianalisis selama lima dekade terakhir menggunakan dimensi, kerangka teoritis dan pendekatan yang berbeda. Terdapat tiga jenis pendekatan untuk menggambarkan kekuatan pendorong dalam keputusan belanja konsumen yaitu pendekatan tipologi konsumen, pendekatan gaya hidup dan pendekatan karakteristik konsumen. ${ }^{44}$ Menurut Lyonski diantara tiga pendekatan tersebut, pendekatan karakteristik merupakan pendekatan yang paling kuat karena fokus pada orientasi mental konsumen dalam mengambil keputusan. ${ }^{45}$ Delapan pendekatan karakteristik sebagai karakteristik mental yang paling dasar dari pengambilan keputusan konsumen dalam membelanjakan uangnya yang dikenal dengan Consumer Style Inventory (CSI), terdiri dari : ${ }^{46}$

\footnotetext{
${ }^{41}$ Monzer Kahf, The Islamic Economis: Analytical Study of the Functioning of the Islamic Economic System, (Plainfield, Indiana: The Muslim Students' Association of the United States and Canada :1979), 24.

${ }^{42}$ Afzalur Rahman, Economic Doctrines of Islam jilid 2, terj. Soeroyo,dkk. (Jakarta: Dana Bhakti Wakaf, 1995), 59.

${ }^{43}$ Afzalur Rahman, Economic Doctrines of Islam jilid 2, 30-33.

${ }^{44}$ F. Lotfizadeh, "Religion and Family Structure: Two Factors Affecting on Consumer Decision Making Styles in Iran, Int. J. Manag. Bus. Res., 3 (2), 2013, 108.

${ }^{45}$ Anubhav Anand Mishra, "Consumer Decision-Making Styles and Young-Adult Consumers: An Indian Exploration,” İşletme Araştırmaları Dergisi 2/3 (2010): 48.

${ }^{46}$ George B. Sproles and Elizabeth L. Kendall, "A Short Test of Consumer DecisionMaking Styles,” The Journal of Consumer Affairs, Volume 5 (1987):7 lihat juga Safiek Mokhlis, "Religious Contrasts in Consumer Shopping Styles: A Factor Analytic Comparison,” 53, F. Lotfizadeh, "Religion and Family Structure: Two Factors Affecting on Consumer Decision Making Styles in Iran,” Int. J. Manag. Bus. Res., 3 (2) (Spring: 2013) :107-119.
} 
1. Perfeksionis, merupakan sebuah pengukuran tentang sejauh mana kesadaran konsumen terhadap kualitas barang.

2. Brand Conscious (Kesadaran terhadap merek), sebuah pengukuran terhadap konsumen untuk membeli produk dengan merek tertentu dengan harga yang mahal.

3. Fashion conscious (kesadaran terhadap mode) pengukuran kegemaran konsumen terhadap produk-produk baru dan inovatif dan menemukan kebahagiaan tersendiri ketika berbelanja terhadap hal-hal tersebut.

4. Rereational Conscious (Hedonistic), mengukur sejauh mana konsumen menjadikan belanja sebagai kegiatan yang menyenangkan dan menjadikan toko-toko sebagai tempat yang menyenangkan.

5. Price Conscious (Kesadaran harga), mengidentifikasi konsumen terhadap kesadaran harga suatu produk dan kebanyakan memilih produk dengan harga murah.

6. Impulsive Buying, mengidentifikasi konsumen yang memiliki kecenderungan untuk membeli secara tiba-tiba tanpa direncanakan dan selalu membeli dan tidak peduli berapa banyak telah menghabiskan keuangan melalui kegiatan membeli tersebut.

7. Confuse Overchoice consumen, mengidentifikasi kebingungan konsumen terhadap beragamnya merek akan suatu produk dan toko-toko sehingga mereka memperoleh informasi yang terlalu banyak.

8. Habitual, mengidentifikasi konsumen yang memiliki toko dan merek favorit sehingga belanja terhadap merek dan di toko tersebut menjadi suatu kebiasaan.

Ada konsensus umum di kalangan para peneliti bahwa perilaku pengambilan keputusan konsumen dapat bervariasi di seluruh budaya. Dengan demikian, Consumer Styles Inventory (CSI) dalam bentuk aslinya tidak dapat digeneralisasi ke berbagai negara tanpa modifikasi. ${ }^{47}$ Instrumen penelitian CSI ini telah digunakan di beberapa negara, diantaranya malaysia ${ }^{48}$, china ${ }^{49}$, India ${ }^{50}$,

\footnotetext{
${ }^{47}$ Anubhav Anand Mishra, "Consumer Decision-Making Styles and Young-Adult Consumers: An Indian Exploration,” 50.

${ }^{48}$ Safiek Mokhlis, "Religious Contrasts in Consumer Shopping Styles: A Factor Analytic Comparison," 52-64.

${ }^{49}$ Hai Bo Xue dan Xin Xin Wang, "Face Consciousness and Decision-making Styles: An Empirical Study of Young-adult Chinese Consumers," International Journal of China Marketing vol. 2(2) 2012: 60-73, Yao Zeng, "An Investigation of Decision-Making Style of Chinese College Student Online Apparel Shoppers," Thesis Graduate Faculty of the Louisiana State University and Agricultural and Mechanical College (2008): 1-84.
}

36 I INDO-ISLAMIKA, Volume 2, Nomor 2, 2015/1437 
Afrika $^{51}$, dan lain-lain. Penelitian tersebut mengkonfirmasi semua bagian dari indikator Consumer Styles Inventory (CSI) yang asli namun tidak semua penelitian tersebut menggunakan semua indikator tersebut. Studi lintas budaya tersebut menunjukkan bahwa empat indikator yang biasa digunakan quality conscious, brand conscious, fashion conscious dan recreational conscious. ${ }^{52}$ Pada penelitian ini penulis menggunakan empat indikator yang diarahkan pada konsumsi berlebihan yaitu brand conscious, fashion conscious and recreational conscious, dan impulsive.

\section{Pengaruh Tingkat Religiusitas terhadap Tingkat Konsumerisme}

Alat ukur religiusitas yang digunakan dalam penelitian ini adalah alat ukur tingkat religiusitas CMIR (Comprehensive Measure of Islamic Religiosity) menurut Habib Tiliouine dan Abbes Belgoumidi yang terdiri dari 4 dimensi, yaitu Religious Belief (Keyakinan keagamaan), Religious Practice (praktek keagamaan), Religious Altruism (altruisme), dan Religious Enrichment (memperkaya pengetahuan keagamaan). ${ }^{53}$ Adapun tingkat religiusitas mahasiswa adalah :

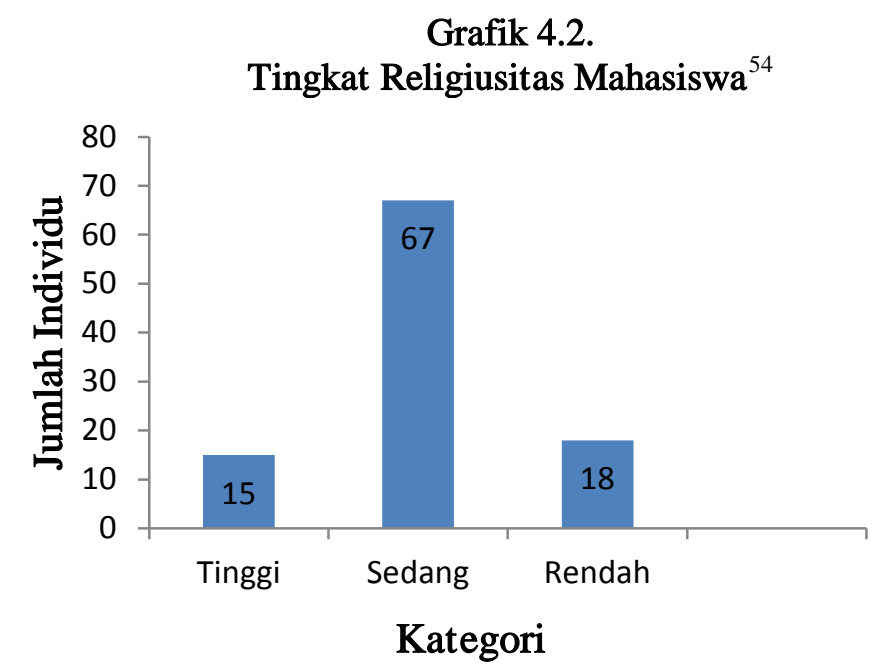

${ }^{50}$ Anubhav Anand Mishra, “Consumer Decision-Making Styles and Young-Adult Consumers: An Indian Exploration,” 45-62.

${ }^{51}$ Laetitia Radder, et.all, "Decision-Making Styles of Young Chinese, Motswana and Caucasian Consumers in South Africa: An Exploratory Study," Tydskrif vir Gesinsekologie en Verbruikerswetenskappe, Vol 34, (2006): 20-31.

${ }^{52}$ Anubhav Anand Mishra, “Consumer Decision-Making Styles and Young-Adult Consumers: An Indian Exploration,” 49.

${ }^{53}$ Habib Tiliouine dan Abbes Belgoumidi, “An Exploratory Study of Religiosity, Meaning in Life and Subjective Wellbeing in Muslim Students from Algeria.” The International Society for Quality-of-Life Studies (ISQOLS) (2009): 115.

${ }^{54}$ Hasil pengolahan data penelitian yang dilakukan oleh penulis tanggal 29 Maret 2014. 
Grafik tersebut menunjukkan bahwa persentase mahasiswa muslim mayoritas berada pada kategori sedang, sehingga bisa dikatakan bahwa tingkat religiusitas mahasiswa bisa di kategorikan baik. Perbedaan tingkat religiuisitas pada mahasiswa dipengaruhi oleh lingkungan keluarga. Sebagaimana menurut Susy YR Sanie Herman menyimpulkan bahwa keluarga yang terpelajar sangat memperhatikan penddidikan dan keberhasilan anak di sekolah, sehingga menghasilkan individu yang terpelajar juga. Keluarga ulama yang saleh cenderung ketat dalam pelaksanaan ibadah dan penerapan nilai-nilai agama dalam perilaku anggota keluarganya, sehingga menghasilkan anak yang menjadi individu yang saleh atau yang tinggi tingkat religiusitasnya juga. ${ }^{55}$

Lingkungan yang terbentuk di kampus atau tempat tinggal juga mempengaruhi tingkat religiusitas seseorang. Menurut Batson, Schoenrade, dan Ventis dalam A. Rusydi menjelaskan bahwa religiusitas dipengaruhi oleh lingkungan sosial, misalnya dengan belajar mengamati (observational learning), penguatan perilaku (reinforcement), tekanan norma dan budaya, dan perubahan sosial. $^{56}$

Namun menurut Laurence $\mathrm{R}$ Iannaccone menyatakan bahwa tingkat religiusitas dan partisipasi aktivitas keagamaan tidak menurun atau tidak dipengaruhi oleh peningkatan pendidikan keagamaan atau pendapatan. ${ }^{57}$ Seseorang yang sangat religius akan menunjukkan komitmen yang kuat terhadap sistem kepercayaan mereka dan dengan demikian akan berprilaku sesuai dengan norma yang diajarkan agama yang dianutnya. ${ }^{58}$ Selanjutnya penulis akan memaparkan tingkat konsumerisme mahasiswa, yaitu :

\footnotetext{
${ }^{55}$ Susy YR Sanie Herman, Teori Ekonomi Mikro tentang Agama: Pengaruh Religiusitas terhadap Perilaku Ekonomi , 64. Selatan)

${ }^{56}$ Ahmad Rusydi, Religiusitas dan Kesehatan Mental (Studi pada Jamaah Tabligh Jakarta

${ }^{57}$ Laurence R Iannaccone, “Religious Participation: A Human Capital Approach,” Journal for Scientific Study of Religion (JSSR) (1990), 297.

${ }^{58}$ Charles Y. Glock dan Rodney Stark, American Piety: The Nature of Religious Comitment (Barkeley: University of California Press, 1968).
}

38 I INDO-ISLAMIKA, Volume 2, Nomor 2, 2015/1437 


\section{Grafik 3.6.}

Tingkat Konsumerisme

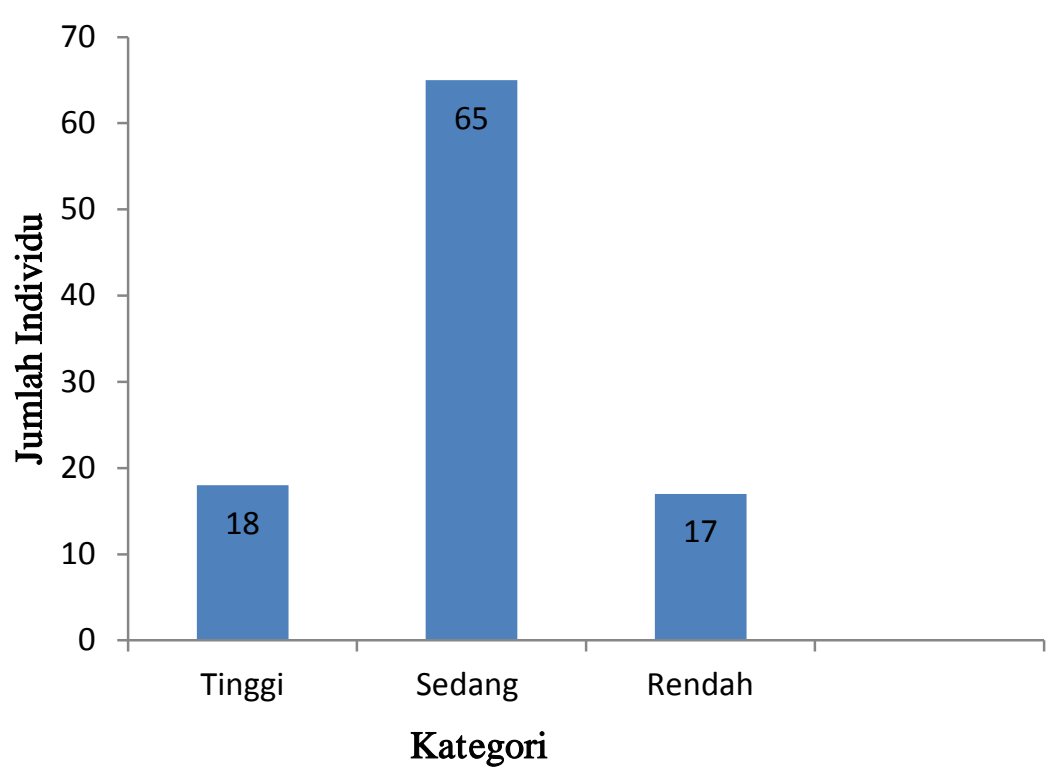

Salah satu pemicu konsumerisme adalah Strategi pemasaran dalam kapitalisme global karena yang diutamakan dalam strategi pemasaran bukan barang atau nilai guna barang, melainkan nilai-nilai lain, seperti nilai prestise dan mode, yang diintrodusir melalui strategi advertising yang jitu. Misalnya saja pada sarana telekomunikasi, Sarana telekomunikasi yang multi fungsi kian berkembang dan sangat dibutuhkan, termasuk smartphone. Seiring peningkatan kebutuhan smartphone, aplikasi terhadap ponsel pada umumnya dan juga smartphone khususnya kian berkembang. Software dan hardware smartphone juga kian beragam dengan harga yang semakin terjangkau. ${ }^{59}$ Kegunaan dan kualitas suatu barang dengan demikian tak lebih dari justifikasi yang dibuatbuat konsumen untuk membeli produk itu. Rasionalitas suatu produk dengan demikian hanyalah "alibi" bagi suatu aksi konsumsi. ${ }^{60}$

Media massa mengulas semua fitur-fitur baru pada sarana telekomunikasi tersebut misalnya saja handphone yang hampir semua mahasiswa memilikinya dan media massa mengulas juga kegunaan pada masing-masing fitur tersebut namun terkadang pembeli bisa jadi hanya menggunakannya untuk mengakses

\footnotetext{
${ }^{59}$ Chuzaimah and others, "Smartphone : antara Kebutuhan dan E-Lifestyle," Seminar Nasional Informatika (2010), 312.

${ }^{60}$ Jean Baudrillard, For A Critique of the Political Economy of the Sign, terj. C. Levin (Telos Press, 1981), 55.
} 
akun facebook mereka semata ${ }^{61}$. Tidak semua mahasiswa memaksimalkan penggunaan smartphone walaupun memiliki 3 handphone sekaligus, karena seyogyanya handphone yang merupakan sarana komunikasi terkadang di tinggalkan saja di kamar karena merasa repot membawanya, namun ketika orang lain bertanya apakah memiliki PIN, atau ID line, akun twitter dan media sosial lainnya maka mahasiswa tersebut memilikinya. ${ }^{62}$

Survei yang dilakukan Sillicon Alley Insider menunjukkan bahwa diantara pengguna $i P a d$ hanya sekitar 21\% yang memanfaatkan fitur-fitur baru dari $i P a d$. Sebagian besar pengguna masih banyak yang hanya memanfaatkan $i P a d$ untuk mengakses internet dan jejaring sosial. ${ }^{63}$ Komoditas yang dimliki seharusnya memiliki manfaat untuk pemiliknya dan pemanfaatan yang maksimal oleh pemilik komoditas tersebut.

Perbedaan kebutuhan fisiologis dipengaruhi oleh perbedaan faktor psikologis, sehingga melahirkan berbagai bentuk kebutuhan hedonistik konkrit, materialistik dan wasteful seperti cita rasa seni, kesombongan atau kemewahan. Berbagai konsumsi dan kekayaan oligarkis seperti mengendarai lamborghini (meskipun lalu lintas padat, macet dan banjir), bermain golf di Australia (untuk alasan bisnis dan lobi relasi), berburu lukisan yang sedang naik daun (sebagai bentuk citarasa seni tinggi), nonton konser karya Chopin sambil berburu jam Chopard terbaru di Wina (untuk menunjukkan status sosial), bukan merupakan akhlak konsumen Islami. Pada akhirnya konsumsi tersebut mengabaikan keharmonisan dan keseimbangan sosial akibat sikap yang individualistik sebagai konsekuensi kelebihan kekayaan dan untuk mencapai kepuasan maksimum. ${ }^{64}$

Semakin tinggi sebuah peradaban, maka masyarakat semakin terkalahkan oleh kebutuhan fisiologik karena faktor-faktor psikologis. Selera, keangkuhan, motivasi untuk pamer, dan sebagainya merupakan variabel yang dominan dalam menentukan bentuk konkrit dari kebutuhan fisiologik. Peradaban materialistik barat telah menghancurkan kesederhanaan dari kebutuhan konsumsi masyarakat. ${ }^{65}$

Menurut Muhammad Abdul Mannan peradaban matrealis barat telah membuat semakin luasnya macam dan bentuk kebutuhan konsumsi dalam mencapai kesejahteraan. Kesejahteraan bagi peradaban matrealis barat diukur

\footnotetext{
${ }^{61}$ http://www.businessinsider.com/how-people-really-use-the-ipad-our-exclusive-surveyresults-2011-5尹30-of-peoplesurveyed-have-more-than-one-ipad-in-their-home-2.

${ }^{62}$ Mahasiswa UIN Syarif Hidayatullah Jakarta, wawancara di lingkungan kampus UIN.

${ }^{63}$ Laporan grafis survey tersebut dapat dilihat di http://www.businessinsider.com/howpeople-really-use-the-ipad-our-exclusive-survey-results-2011-5\&0-of-peoplesurveyed-have-morethan-one-ipad-in-their-home-2.

${ }^{64}$ Arif Pujiyono, “Teori Konsumsi Islami,” : 197.

${ }^{65}$ Muhammad Abdul Mannan, Teori dan Praktek Ekonomi Islam, 45.
} 
berdasarkan sifat kebutuhan yang diusahakannya untuk memenuhi suatu kepuasan khusus (self service). Dari segi kemajuan suatu masyarakat, peradaban barat menilai bahwa kemajuan suatu masyarakat dinilai dari sifat kebutuhankebutuhan materialnya. Artinya, semakin tinggi tingkat hidup masyarakat, maka akan semakin luas kebutuhan-kebutuhan mereka yang akan menambah perasaan tidak puas dan kekecewaan, sehingga nafsu untuk mengejar tingkatan konsumsi akan terus bertambah. ${ }^{66}$ Nafsu untuk mengejar tingkatan konsumsi ini akan menimbulkan perilaku konsumsi yang berlebihan, perilaku konsumsi yang mengutamakan keinginan daripada kebutuhan, dan perilaku konsumsi yang mengutamakan barang-barang mewah sebagai kebutuhan, saat ini perilaku tersebut lebih dikenal dengan konsumerisme.

Hegemoni konsumerisme yang dibangkitkan dalam premis perilaku konsumen ekonomi barat telah memburamkan cita-cita keadilan dan kesejahteraan. Dalam keadaan seperti ini, masyarakat sulit sekali menggerakkan dirinya untuk mencintai, mengasihi dan peduli kepada nasib orang lain, karena setiap orang lebih menyukai untuk berlomba-lomba dalam kekayaan dan mencari kesenangan sendiri, sehingga hal ini dikhawatirkan akan berdampak pada distribusi kekayaan dari yang kaya kepada yang miskin yang tidak merata.

Munculnya perilaku konsumsi yang lebih mengutamakan keinginan daripada kebutuhan tersebut menurut sumartono disebabkan oleh dua faktor, yaitu faktor internal ${ }^{67}$ dan eksternal. Faktor Internal terdiri dari motivasi, harga diri, observasi, proses belajar, kepribadian, dan konsep diri. Sedangkan faktor Eksternal terdiri dari kebudayaan, kelompok sosial, referensi dan keluarga. ${ }^{68}$ Dengan besarnya pengaruh tersebut diharapkan adanya variabel efektif yang dapat mengurangi konsumerisme di kalangan mahasiswa, diantara variabel yang dapat mengurangi tersebut adalah konsep diri, pendidikan keluarga dan lain-lain.

Menurut F. Lotfizadeh ada banyak variabel psikologis dan variabel sosial yang efektif yang dapat memandu dan mempengaruhi keputusan konsumsi seseorang. Salah satu variabel tersebut adalah budaya yang merupakan dasar dari perilaku konsumsi individu. Budaya memiliki banyak variabel dan variabel

\footnotetext{
${ }^{66}$ Muhammad Abdul Mannan, Teori dan Praktek Ekonomi Islam, 45.

${ }^{67}$ Menurut Engel, Blackwell dan Miniard perbedaan-perbedaan dalam perilaku konsumen merupakan manifestasi dari adanya perbedaan-perbedaan di dalam proses pengambilan keputusan yang antara lain dipengaruhi oleh adanya perbedaan-perbedaan individual.

${ }^{68}$ Sumartono, Terperangkap dalam Iklan: Menerobos Imbas Pesan Iklan Televisi, (Bandung: Alfabeta, 2002) Ada 8 indikator konsumtif menurut sumartono yaitu membeli produk karena iming-iming hadiah, membeli produk karena kemasannya menarik, membeli produk karena demi menjaga penampilan diri dan gengsi, membeli produk atas pertimbangan harga (bukan atas dasar manfaat atau kegunaannya, membeli produk hanya sekedar menjaga simbol status, memakai produk menurut sumartarena unsur konformitas terhadap model yang mengiklankan, munculnya penilaian bahwa membeli produk dengan harga mahal akan menimbulkan rasa percaya diri yang tinggi, dan mencoba lebih dari dua produk sejenis (merek berbeda).
} 
paling penting dari budaya tersebut adalah agama. Variabel ini dianggap sebagai variabel yang memiliki kekuatan untuk mengarahkan seseorang sepanjang hidupnya, dalam agama Islam dikatakan bahwa agama merupakan jalan hidup (way of life). ${ }^{69}$

Apabila manusia banyak dikendalikan oleh unsur hati dan ruhnya yang suci, maka perilaku yang etis dan religius akan selalu tampak dalam kehidupan sehari-hari, kedamaian, dan kemakmuran yang menjadi dambaan semua manusia di dunia ini akan selalu tercipta. Sebaliknya jika nafsu yang mendominasi maka keserakahan merajalela, kehancuran mengancam stabilitas kehidupan sosial. ${ }^{70}$ Untuk mengetahui besarnya pengaruh dimensi-dimensi religiusitas yang telah diuraikan diatas meliputi religious belief, religious practice, religious altruism, dan religious enrichment bersama-sama terhadap konsumerisme, dapat digunakan analisis koefisien determinasi (KD) yaitu sebagai berikut :

Tabel 4.1.

Hasil Uji Regresi untuk Kontribusi

\begin{tabular}{|c|c|c|}
\hline $\begin{array}{c}\text { Variabel } \\
\text { Independent }\end{array}$ & Variabel dependent & \multicolumn{2}{|c|}{ Kontri } \\
\hline Religiusitas & Konsumerisme & $56,5 \%$ \\
\hline
\end{tabular}

Berdasarkan hasil perhitungan SPSS diperoleh nilai koefisien determinasi sebesar 56,5\%, berarti tingkat religiusitas memiliki pengaruh sebesar 56,5\% untuk mengurangi tingkat konsumerisme mahasiswa muslim yang ditentukan oleh dimensi-dimensi religiusitas yang meliputi religious belief, religious practice, religious altruism, dan religious enrichment secara bersama-sama dan sisanya 43,5\% dipengaruhi oleh faktor lain. ${ }^{71}$

Asumsi ekonomi yang mengatakan bahwa kebutuhan manusia itu tidak terbatas pada dasarnya berakar dari etika hedonisme, khususnya hedonisme kuantitatif. Pelopor aliran etika ini adalah aristippus dan dikembangkan lebih lanjut oleh Epicurus (341-271 SM). Etika hedonisme pada intinya mengajarkan

\footnotetext{
${ }^{69}$ F. Lotfizadeh, "Religion and Family Structure: Two Factors Affecting on Consumer Decision Making Styles in Iran, Int. J. Manag. Bus. Res., 3 (2), 2013,111-119.

${ }^{70}$ Muhammad, Prinsip-prinsip Ekonomi Islam (Yogyakarta: Graha Ilmu, 2007): 77.

${ }^{71} \mathrm{R}$ Square untuk menentukan proporsi atau presentase total variasi dalam variabel terikat yang diterangkan variabel bebas secara bersama-sama. Pada regresi sederhana yang dilihat adalah

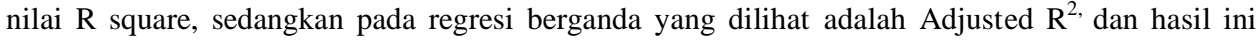
dilihat dari output model summary, Hasil pengolahan data penelitian yang dilakukan oleh penulis tanggal 29 Maret 2014.
}

42 I INDO-ISLAMIKA, Volume 2, Nomor 2, 2015/1437 
manusia untuk mengejar kenikmatan dan berupaya semaksimal mungkin untuk menghindari hal-hal seperti penderitaan, rasa sakit, rasa sedih dan sebagainya. ${ }^{72}$

Dalam lingkungan sekularis pemenuhan kepentingan diri sendiri dan maksimalisasi keinginan dan kepemilikan barang-barang materil merupakan tujuan utama dalam aktifitas manusia. ${ }^{73}$ Sedangkan Islam menolak terhadap paham materialis, Islam melaknat orang yang menganggap kepuasan untuk mencapai kehendak-kehendak ekonomi sebagai suatu keharusan bagi dirinya. ${ }^{74}$

Islam menolak asumsi bahwa semua keinginan itu sama pentingnya dan semua keinginan yang tidak terbatas itu harus terpuaskan. Akan tetapi, Islam mengatur bahwa manusia hanya memerlukan sejumlah kebutuhan. sejumlah kebutuhan lebih penting dan sejumlah kebutuhan lainnya kurang penting. Kebutuhan yang lebih penting dipenuhi terlebih dahulu baru kebutuhan lainnya. Prinsip-prinsip dasar ini tidak saja mengandung pengertian normatif tetapi juga positif. Peradaban manusia tidak dapat memenuhi semua keinginan yang sama pentingnya. Oleh karena itu ada keinginan yang lebih penting dan kurang penting, sehingga keinginan yang lebih penting harus dipenuhi terlebih dahulu. ${ }^{75}$

Menurut Lukman Fauroni pada tingkatan praktis, prilaku ekonomi (economic behavior) sangat ditentukan oleh tingkat religiusitas seseorang atau sekelompok orang yang kemudian membentuk kecenderungan perilaku konsumsi. Dengan demikian dapat disimpulkan tiga karakteristik perilaku ekonomi dengan menggunakan tingkat religiusitas sebagai asumsi, yaitu: ${ }^{76}$

1. Ketika religiusitas ada pada tingkat yang cukup baik, maka motif berkonsumsi akan didominasi oleh tiga motif utama yaitu maslahah, kebutuhan dan kewajiban.

2. Ketika religiusitas ada pada tingkat yang kurang baik, maka motifnya tidak didominasi hanya oleh tiga hal tadi tapi juga kemudian akan dipengaruhi secara signifikan oleh ego, rasionalisme (materialisme) dan keinginan-keinganan yang bersifat individualistis.

\footnotetext{
${ }^{72}$ Muhammad, Prinsip-prinsip Ekonomi Islam , (Yogyakarta: Graha Ilmu, 2007),87.

${ }^{73}$ Umer Chapra, The Future of Economic An Islamic Walfare (United Kingdom: The Islamic Foundation), 123.

${ }^{74}$ Afzalur Rahman, Doktrin Ekonomi Islam, 20-23.

${ }^{75}$ Euis Amalia, “Teori Perilaku Konsumen dalam perspektif Ekonomi Islam,” 10-11.

${ }^{76}$ Lukman Fauroni, "Produksi Dan Konsumsi Dalam Al-Qur’an: Aplikasi Tafsir Ekonomi Al-Qur'an,” 10.

http://www.google.co.id/url?sa=t\&rct=j\&q=\&esrc=s\&source=web\&cd=1\&cad=rjauact=8 \&ved=0CBoQFjAA\&url=http\%3A\%2F\%2Fwww.ditpertais.net $\% 2$ Fannualconference $\% 2$ Fancon0 6\%2Fmakalah\%2FMakalah\%2520Lukman\%2520Fauroni.doc\&ei=ZxWxUqUE8eyuASV9oCwA Q\&usg=AFQjCNF4z0d_hbqhqd9NoMpNPIAPp-K-Fw
} 
3. Ketika religiusitas ada pada tingkat yang buruk, maka motifnya tentu saja akan didominasi oleh nilai-nilai individualistis (selfishness), ego, keinginan dan rasionalisme.

Menurut Mangunwijaya religiusitas mempunyai makna yang berbeda dengan religi atau agama. Kalau agama menunjuk pada aspek formal yang berkaitan dengan aturan-aturan dan kewajiban-kewajiban, sedangkan religiusitas menunjuk pada aspek religi yang telah dihayati oleh individu di dalam hati. Seseorang bisa dikatakan religius (fisik dan hati), jika dalam kesehariannya memang baik, berperilaku indah, beribadah tanpa mau mendapatkan perhatian orang lain, tidak korupsi uang, waktu dan hal-la lain yang tidak sesuai dengan ajaran agamanya. ${ }^{77}$

Religiusitas memiliki kontribusi 56,5\% dalam mengurangi konsumerisme di kalangan mahasiswa. Dan sebesar 43,5\% dapat dijelaskan oleh faktor lain yang tidak diteliti pada penelitian ini. Maka hasil ini menggambarkan bahwasanya religiusitas bukan merupakan satu-satunya faktor yang dapat membendung konsumerisme di kalangan mahasiswa muslim karena masih banyak faktor-faktor lain yang berpengaruh untuk menghindarkan diri dari konsumerisme.

Setelah membahas kontribusi religiusitas terhadap konsumerisme selanjutnya akan dilakukan analisa melalui regresi sederhana untuk mengetahui bagaimana pengaruh religiusitas terhadap konsumerisme mahasiswa muslim. Sebagai prasyarat diterapkannya analisis regresi dilakukan uji asumsi klasik yang terdiri dari uji normalitas, uji linieritas, uji multikoliniearitas, uji

\footnotetext{
${ }^{77}$ Matdon, “Religiusitas Koruptoriyah,” Sabtu, 14 Desember 2013 http://www. koransindo.com/node/351258. Pengamat politik dari Universitas Warmadewa (Unwar) Denpasar, I Wayan Gede Saucana berpendapat bahwa gaya hidup konsumerisme di kalangan pejabat dapat memicu terjadinya tindak pidana korupsi. Tingginya standar ekonomi itu dapat dilihat dari pengeluaran pelaku korupsi untuk membeli atau membiayai kendaraan, tempat tinggal, dan pergaulan sehari-hari. Terjadinya hubungan yang positif antara konsumerisme dan korupsi dapat juga dilihat dari kasus-kasus korupsi akhir-akhir ini yang banyak melibatkan pejabat di Indonesia yang bergama Islam, paham agama dengan baik, tidak meninggalkan kewajiban-kewajiban seperti shalat,puasa, haji dan kewajiban-kewajiban lainnya. Konsumerisme Pejabat Picu Tindakan Korupsi, 01 Januari 2014, http: //www.republika.co.id/berita/nasional/ hukum/ 14 / 01/ 01/ myq0pj konsumerme-pejabat-picu-tindakan-korupsi. Dua ciri religiusitas yang paling mendasar adalah hubungan sosial dan meyakini "hari depan”. Korupsi-manipulasi dan mafia birokrasi dalam bentuk apapun akan merugikan kepentingan orang lain dengan skala yang luas. Dengan demikian, koruptor dan mafia birokrasi telah menunjukkan bukan ciri mahluk yang religius. Apalagi, seorang koruptor dan mafia birokrasi tentunya tidak akan mempertimbangkan "hari depan" sebab mereka tidak memandang masa depan generasi berikutnya. Bahkan mereka tidak akan memikirkan hukuman dan ganjaran dari Tuhan mengenai perilakunya tersebut. Oleh karena itu, koruptor bukan saja disebut orang yang tidak religius tetapi juga tidak meyakini adanya Tuhan dan segala kuasaNya (atheis). Ghazali Bagus Ani Putra agama, korupsi dan mafia birokrasi http://pks.psikologi.unair.ac.id/ coretan kami/agama korupsi dan mafia birokrasi/
} 
heterokedastisitas, dan uji autokorelasi. Setelah dilakukan uji asumsi klasik tersebut didapatkan hasil bahwa data hasil kuesioner layak dilakukan analisis regresi linier sederhana. ${ }^{78}$

Untuk mengetahui religiusitas berpengaruh terhadap tingkat konsumerisme dilakukan analisis regresi sederhana dengan dasar pengambilan keputusan taraf uji 10\% $(\alpha=0,1)$ adalah jika p- value lebih kecil dari 0,1 maka Ha diterima. Berdasarkan hasil perhitungan SPSS dengan melihat tabel ANOVA $^{\mathrm{b}}$, maka diperoleh nilai p-value (sig) sebesar 0,000, dengan demikian maka Ha diterima yaitu terdapat pengaruh antara tingkat religiusitas dan tingkat konsumerisme karena p-value lebih kecil dari nilai $\alpha(0,0000<0,1)$. Hal ini menunjukkan bahwa terdapat pengaruh yang signifikan antara religiusitas dan konsumerisme. ${ }^{79}$ Berikut ini merupakan tabel uji regresi sederhana dengan melihat tabel Coefficients ${ }^{\mathrm{a}}$, yaitu:

Tabel 4.2.

Hasil Uji Regresi Sederhana

\begin{tabular}{|c|c|c|cc|}
\hline $\begin{array}{c}\text { Variabel } \\
\text { Independent }\end{array}$ & $\begin{array}{c}\text { Variabel } \\
\text { dependent }\end{array}$ & $\begin{array}{c}\text { T } \\
\text { hitung }\end{array}$ & \multicolumn{2}{|c|}{ Sig } \\
\hline Religiusitas & Konsumerisme & $\begin{array}{c}- \\
0,0\end{array}$ & \multicolumn{2}{|c|}{00} \\
\hline
\end{tabular}

Berdasarkan hasil perhitungan SPSS dengan melihat tabel Coefficients ${ }^{\mathrm{a}}$, maka diperoleh nilai t hitung sebesar $-11,288$, t hitung bernilai negatf sehingga hal ini menunjukkan bahwa pengaruh religiusitas terhadap konsumerisme menunjukkan hubungan negatif, bahwa jika skor religiusitas bertambah maka skor konsumerisme akan berkurang. ${ }^{80}$

Dalam ekonomi Islam tujuan konsumsi adalah masflahgh, dengan paradigma masłahłh seseorang akan dapat melakukan filter dalam konsumsi, mampu membuat skala prioritas kebutuhan atau need berdasarkan tiga tingkatan

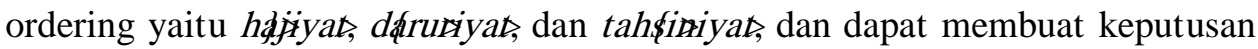
pilihan konsumsi yang tepat dalam kerangka efisiensi. Terciptanya keseimbangan merupakan salah satu tujuan ekonomi Islam, mewujudkannya dengan menjauhi konsumerisme, karena apabila keseimbangan ini terganggu maka akan terjadi ketimpangan-ketimpangan sosial ekonomi dalam kehidupan

\footnotetext{
${ }^{78}$ Hasil uji asumsi klasik merupakan pengolahan data penelitian yang dilakukan oleh penulis tanggal 29 Maret 2014.

${ }^{79}$ Tabel ANOVA Hasil pengolahan data penelitian yang dilakukan oleh penulis tanggal 29 Maret 2014. Maret 2014.

${ }^{80}$ Tabel ANOVA Hasil pengolahan data penelitian yang dilakukan oleh penulis tanggal 29
} 
masyarakat, seperti kelaparan, kemiskinan di tengah-tengah kekayaan, kelangkaan tenaga kerja dan lain-lain. ${ }^{81}$ Konsumerisme yang dipengaruhi oleh keinginan-keinginan individu akan mengakibatkan seseorang menjauh dari ajaran agamanya. ${ }^{82}$

Menurut McCleary dan Barro agama memiliki dua interaksi dengan ekonomi, agama dapat dipandang sebagai dependent variabel, yaitu bagaimana perubahan ekonomi dapat mempengaruhi keagamaan dan keyakinan seseorang. Agama dapat juga menjadi independen variabel, yaitu bagaimana agama memberikan karakter pada tiap individu, seperti etika kerja, kejujuran, berhemat, dan performa ekonomi yang lain. ${ }^{83}$ Pada penelitian ini agama dalam bentuk religiusitas menjadi independen variabel yang menentukan perilaku konsumsi seorang individu. Dengan religiusitas yang tinggi maka akan memberikan karakter yang baik pada individu dalam berhemat dan performa ekonomi yang berupa perilaku konsumsi.

Tingkatan religiusitas yang memberikan pengaruh terhadap konsumerisme jika berdasarkan penelitian Syed Nizar Hussaini Hamdani adalah pada tingkatan sangat religius, yaitu individu yang memiliki sikap positif, berperilaku baik, praktek keagamaan yang sangat baik, jujur dalam semua urusan, memiliki kepribadian yang bisa diandalkan. ${ }^{84}$ Sebagaimana hasil perhitungan SPSS individu yang berada pada kategori tinggi untuk tingkat religiusitas maka akan berada pada kategori rendah untuk tingkat konsumerisme. Tingkat religusitas ditunjukkan individu dengan melaksanakan praktek keagamaan yang sangat baik, sering membantu sesama sehingga mencerminkan berprilaku baik terhadap sesama, memiliki pribadi yang bisa diandalkan, menambah pengetahuan ilmu agama, dan menghindarkan diri dari perbuatan-perbuatan yang dilarang agama, sehingga hal ini mencerminkan pribadi yang jujur, beberapa sikap tersebut di atas sesuai dengan kriteria individu yang sangat religius. Menurut safiek mokhlis individu yang taat tidak

\footnotetext{
${ }^{81}$ Rinda Asytuti, "Rekonsepsi Ekonomi Islam dalam Perilaku dan Motivasi Ekonomi,” Religia, Vol.14 No. 1 April 2011, 84.

${ }^{82}$ Pemikiran ini brawal dari penelitian terhadap masyarakat yahudi di Israel, karena pada hari sabtu justru banyak yang menghabiskan waktu mereka dengan berbelanja ke mall-mall. Kebiasaan berbelanja ini menyebabkan masyarakat yahudi Israel tidak beribadat ke tempat peribadatan. Hal ini muncul karena pengaruh globalisasi. Guy Ben-Porat and Yariv Feniger, "Live and Let Buy? Consumerism, Secularization, and Liberalism," Comparative Politics, Vol. 41, No. 3 (April 2009), 293-313

http://www.jstor.org/stable/40599226 .Accessed: 22/12/2013.

${ }^{83}$ Rachel M. McCleary and Robert J. Barro, "Religion and Eonomy," Journal Of Economic perspective, Vol. 20 (Spring: 2006): 49-72.

${ }^{84}$ Syed Nizar Hussaini Hamdani, "Religious Orientation as a Factor in Time Allocation: Evidence from Cross-Section Pakistani Data," Ph. D. Dissertation in Quiad-i-Azzam University Pakistan, (2000): 62.
} 
akan belanja secara impulsif (salah satu dimensi konsumerisme pada penelitian ini). ${ }^{85}$

Religusitas memberikan pengaruh terhadap konsumerisme, hal ini sangat mungkin terjadi karena, religiusitas sangat penuh dengan nilai-nilai dan normanorma, maka agama menjadikan pemeluknya untuk menjalankan kehidupan sesuai dengan norma dan nilai yang di atur dalam agamanya. Peningkatan religiusitas individu merupakan salah satu upaya untuk menjauhkan seorang individu dari konsumerisme atau perilaku konsumsi yang berlebihan.

\section{Penutup}

Religiusitas memiliki pengaruh signifikan terhadap konsumerisme yaitu semakin tinggi tingkat religiusitas maka akan semakin rendah tingkat konsumerisme mahasiswa. Mayoritas mahasiswa berada pada kategori sedang pada tingkat konsumerisme, dan hal ini menunjukkan bahwa gejala konsumerisme pada kalangan mahasiswa tidak buruk namun mendekati tinggi yang akan menjadi tidak baik. Beberapa temuan dalam penelitian ini membuktikan bahwa religiusitas berpengaruh negatif terhadap tingkat konsumerisme yang ditunjukkan dengan t hitung yang bernilai negatif, dan memberikan kontribusi sebesar 56,5 \%. Yang berarti 43,5 \% sisanya dipengaruhi oleh variabel lain yang tidak diteliti pada penelitian ini, diantaranya adalah konsep diri, kepribadian, pendidikan keluarga, dan lain-lain.

\section{Daftar Pustaka}

Amalia, Euis. “Teori Perilaku Konsumen dalam perspektif Ekonomi Islam.” Jauhar Jurnal Pemikiran Islam kontekstual. Vol.4. No.1 (Juni 2003)

Alam, Syed Shah et.all. "Is religiosity an important determinant on Muslim consumer behaviour in Malaysia?.”Journal of Islamic Marketing Vol. 2 No. 1 (2011): 83-96.

Chapra, M. Umer. Islam dan Pembangunan Ekonomi. Jakarta : Tazkia Institute, 2000.

--------. The Future of Economic An Islamic Walfare (United Kingdom: The Islamic Foundation, 2000.

Chuzaimah, dkk, "Smartphone : antara Kebutuhan dan E-Lifestyle.” Seminar Nasional Informatika, Mei 2010.

Djakfar, Muhammad. Agama, Etika, dan Ekonomi wacana menuju pengembangan Ekonomi Rabbaniyah. Malang: UIN Malang Press , 2007.

\footnotetext{
${ }^{85}$ Safiek Mokhlis, "Relevancy and Measurement of Religiosity in Consumer Behavior Research,” International Business Reasearch Vol. 2, No. 3. (2009): 76.
} 
Fadhilah. "Relevansi logika sosial Konsumsi dengan Budaya Konsumerisme Dalam Perspektif Epistemologi Jean Baudrillard.” Jurnal Kybernan, Vol. 2, No. 1 (2011): 39-57.

Glock, Charles Y. dan Rodney Stark, American Piety : The Nature of Religious Comitment. Barkeley: University of California Press, 1968.

Hamdani, Syed Nizar Hussaini. "Religious Orientation as a Factor in Time Allocation: Evidence from Cross-Section Pakistani Data.” Ph. D. Dissertation in Quiad-i-Azzam University Pakistan (2000): 1-234.

Herek, Gregory M. "Religious Orientation and Prejudice: A Comparison of Racial and Sexual Attitudes.” Personality and Social Psychology Bulletin 13(1) (1987).

Herman, Susy Y.R. Samie. Teori Ekonomi Mikro Agama Pengaruh Religiusitas Terhadap Perilaku Ekonomi, (Banten : CV Efko Grafika, 2012.

Huber, Stefan and Odilo W. Huber. “ The Centrality of Religiosity Scale (CRS).” Religions (2012).

Iannaccone, Laurence R Laurence R. "Religious Participation: A Human Capital Approach.” Journal for Scientific Study of Religion (JSSR)(1990).

Ibrahim, Idi Subandy. Budaya Populer Sebagai Komunikasi. Yogyakarta : Jalasutra, 2007.

Kahf, Monzer. The Islamic Economis: Analytical Study of the Functioning of the Islamic Economic System. Plainfield, Indiana: The Muslim Students' Association of the United States and Canada :1979.

Kamaruddin, Abdul Razak. "Religiosity and Shopping Orientation: A Comparative Study of Malaysia and Thailand Consumers.” (t.t): 1-8.

dan Kamarulzaman Kamaruddin. "Malay culture and consumer decisionmaking styles: an investigation on religious and ethnic dimensions.” Jurnal Kemanusiaan Bil.14. Dis 2009.

Khan, Muhammad Akram. 'The Role of Government in the Economy," The American Journal of Islamic Social Sciences, Vol. 14, No. 2, (1997).

Khraim, Hamza. "Measuring Religiosity in Consumer Research from Islamic Perspective,” International Journal of Marketing Studies Vol. 2, No. 2; (November, 2010).

King, Morton ."Measuring the Religious Variable: Nine Proposed Dimensions.” Journal for the Scientific Study of Religion, Vol. 6, No. 2 (Autumn, 1967): 173-190.

------- and Richard A. Hunt. "Measuring the Religious Variable: Replication.” Journal for the Scientific Study of Religion, Vol. 11, No. 3 (Sep., 1972): 13-22.

Krauss, Steven Eric and others, “The Muslim Religiosity-Personality Measurment Inventory (MRPI)’s Religiosity Measurment Model: Toward Filling The Gaps in Religiosity Research on Muslim.” Pertanika Journal of Social Science and Humanity, 13(2) (Serdang : University Putra Malaysia Press, 2005): 173-186. 
-------“. Adaptation of a Muslim Religiosity Scale for Use with Four Different Faith Communities in Malaysia.” Review of Religious Research, Vol. 49, No. 2 (Dec, 2007), pp. 147-164.

Lee, Martin J. Consumer Culture Reborn, The Cultural Politics of Consumption. London-New York : Routledge, 1993.

Lotfizadeh, F. "Religion and Family Structure: Two Factors Affecting on Consumer Decision Making Styles in Iran.” Int. J. Manag. Bus. Res., 3 (2) (Spring : 2013): 107-119

Mannan, Muhammad Abdul. Economic Development and Social Peace in Islam. Bangladesh: Bangladesh Social Peace Foundation, 1989.

-------.Teori dan Praktek Ekonomi Islam. Yogyakarta : PT Dana Bhakti Wakaf, 1995.

Masyhuri. Ekonomi Mikro. Malang: UIN Malang Press, 2007.

Mokhlis, Safiek. "The Influence of Religion on Retail Patronage Behaviour in Malaysia." Disertation Faculty of Management University of Stirling Scotland UK (2006): 1-554.

--------."Relevancy and Measurement of Religiosity in Consumer Bahavior Research.” International Business Research” Vol 2 No. 3 (2009): 75-84. -."Religious Contrasts in Consumer Shopping Styles: A Factor Analytic Comparison.” Journal of Business Studies Quarterly Vol. 2, No. 1, (2010): 52-64.

Nashori, Fuad dan Rachmy Diana Mucharam. Mengembangkan Kreativitas Dalam Perpektif Psikologi Islam. Yogyakarta : Menara Kudus 2002.

Nugroho. "Modernisme, Pos Modernisme serta kritik terhadap Posmodenisme dalam Ilmu Ekonomi.” Dinamika Pembangunan, vol 3, No 2, Desember 2006: 174-183.

O'Connell, Brian J. "Dimensions of Religiosity among Catholics." Review of Religious Research, Vol. 16, No. 3, (Spring,1975): 198-207.

Patel, Mahesh. Influence of Religion on Shopping Behaviour of Consumers-An Exploratory Study.” Volume NO1, Issue (2009): 68-78.

Rahman, Afzalur. Muhammad Seorang Pedagang, terj. Dwi Nur Juliati, dkk. Jakarta: Yayasan Suara Bhumy, 1995.

-------.Economic Doctrines of Islam jilid 1 dan 2 terj. Soeroyo,dkk. Jakarta: Dana Bhakti Wakaf, 1995.

Rulindo, Ronald and Amy Mardhatillah . "Spirituality, Religiousity And Economic Performances Of Muslim Micro Enterpreneurs." $8^{\text {th }}$ International Conference on Islamic Economics and Finance (2011): 1-13, http://www.conference.qfis.edu.qa/app/media/311 (accessed November 21,2013).

Rusydi, Ahmad. Religiusitas dan Kesehatan Mental (Studi pada Aktivis Jama’ah Tabligh Jakarta Selatan). Ciputat: Young Progressive Muslim, 2012. 
Salleh, Muhammad Syukri. "Religiosity in Development: A Theoretical Construct of an Islamic-Based Development.” International Journal of Humanities and Social Science Vol. 2 No. 14 (Special Issue-July 2012): 266-274.

Shukor, Abdul dan Ahmad jamal, "Developing Scales for Measuring Religiosity in the Context of Consumer Research,” Middle-East Journal of Scientific Research 13 (Research in Contemporary Islamic Finance and Wealth Management, (2013).

Simuh, dkk. Islam dan Hegemoni Sosial. Jakarta: Mediacita, 2002.

Sumartono. Terperangkap dalam Iklan: Menerobos Imbas Pesan Iklan Televisi. Bandung: Alfabeta, 2002.

Suyanto, Bagong. Sosiologi Ekonomi Kapitalisme dan Konsumsi di Era Masyarkat Postmodernisme. Jakarta: Kencana Prenada media Group, 2013.

Tiliouine, Habib and Abbes Belgoumidi. “An Exploratory Study of Religiosity, Meaning in Lifeand Subjective Wellbeing in Muslim Students from Algeria.” The International Society for Quality of Life Studies (ISQOLS) 4 Springer (2009): 109-127.

Vitell, Scott J. “The Role of Religiosity in Business and Consumer Ethics: A Review of the Literature.” Journal of Business Ethics (2009): 155-167.

Wahyuni, Endang Tri. "Faktor-faktor yang Mempengaruhi perilaku Konsumsi Mahasiswa Fakultas Ekonomi Universitas PGRI Yogyakarta.” HUMANITAS, Vol.4 No.2 (2007), 110-123. http://upy.ac.id/ekonomi/files/FaktorFaktor\%20yang\%20mempengaruhi\% 20perilaku\%20konsumsi\%20mahasiswa\%20fakultas\%20ekonomi\%20\%2 0\%20\%28endang\%20tri\%20wahyuni\%29.Pdf.

Worthington, Everett L. and others. "The religious commitment inventory-10: development, refinement and validation of a brief scale for research and counselling.” Journal of Counselling Psychology 50 (1) (2003): 84-96.

Xue, Hai Bo dan Xin Xin Wang. "Face Consciousness and Decision-making Styles: An Empirical Study of Young-adult Chinese Consumers." International Journal of China Marketing vol. 2(2) 2012: 60-73.

Yaacob, Mashitoh. "Ethics of Consumption: Individual Responsibility.” Jurnal Pengajian Umum Bil.5 (t.t).

$\overline{\text { Herlina Yustati, IAIN Bengkulu, hyustati@nail.com }}$ 